日本金属学会誌 第 47 巻 第1 号(1983) $72-79$

\title{
研削加工層における残留忍力とひずみにおよぼす 研削条件の影呫
}

\author{
米谷 茂* 能登谷久公** 高过雄三**
}

J. Japan Inst.Metals, Vol.47, No.1(1983),pp.72-79

On the Influence of Grinding Condition on Residual Stress and

Distortion in Ground Layer

Shigeru Yonetani*, Hisakimi Notoya** and Yuzo Takatsuji**

Up to this time, many researches regarding grinding residual stress have been reported. About the distribution of residual stress below the ground surface, large tensile stress is found in the layer neighboring the surface. Usually it is considered that residual stress may mainly be caused by the heat occurring due to the grinding. Simultaneously, it is necessary to consider that plastic deformation generated under the wheel-work contact zone results in the occurrence of residual stress.

In this report, the authors have investigated residual stress from the above view point. We used carbon steel S45 C as specimens and measured residual stresses of the specimens ground under various grinding conditions.

We measured plastic distortion at each point of the specimens which were taken out in the process of grinding, and investigated the influence of plastic distortion on the occurrence of residual stresses.

(Received July 13, 1982)

Keywords : grinding surface, grinding residual stress, prastic distortion of subsurface, grinding force, grinding temperature, carbon steel

* 金沢大学工学部機械工学科 (Department of Mechanical Engineering, Faculty of Engineering, Kanazawa University, Kanazawa)

** 富山大学工学部生産機械工学科 (Department of Production Engineering, Faculty of Engineering, Toyama University, Takaoka) 


\section{I. 緒 言}

従来, 研削残留応力に関して多くの研究結果が報告され ている(1)〜(5).これらは, 残留応力の発生扣よび 発生状沉 におよぼす研削条件の影響を調べたものが多く，また，そ の残留応力の発生を熱応力によるものとして, 発生機構の 解析を行ったものなどがある(6)〜(10).

普通, 研削面直下で発生している残留応力は, 引張応力 である。この原因として研削熱の発生にともなら熱応力の 影響によることは当然であるが, 研削時, 砥石接触面下で外 部応力により生じる塑性変形の影響をも考慮する必要があ る.しかし従来の研究には, 研削点下の塑性変形を考虑し て残留応力の発生を検討した報告は殆どない(11).

本研究では基本的実験として, 焼鈍した S $45 \mathrm{C}$ 材を, 各 種研削条件で研削を行い, 砥石 - 試料接触面下の塑性ひず みの発生状態や残留応力を詳細に測定し, 残留応力発生に およぼす工作条件の影響や，発生過程についての考察を行 った.

\section{II. 実 験 方 法}

試料は市販の S $45 \mathrm{C} \phi 50 \mathrm{~mm}$ の丸棒を鍛造し， $60 \mathrm{~mm}$ $\times 10 \mathrm{~mm} \times 3 \mathrm{~mm}$ および $60 \mathrm{~mm} \times 10 \mathrm{~mm} \times 15 \mathrm{~mm}$ に機械 仕上げを行った後，無酸化炉で約 $1100 \mathrm{~K}\left(\right.$ 約 $\left.830^{\circ} \mathrm{C}\right)$ に 1.8 $\mathrm{ks}(30 \mathrm{~min})$ 保持後炉冷して加工ひずみを除き実験に供し た.

実験は試料速度と砥石切込み深さを变光て行った。使用 砥石および実験条件をTable 1 に示す。研削抵抗は, 長 八角形リングにひずみゲージを貼付した研削動力計 ${ }^{(12)}$ 自製し測定した。 また研削温度の測定を行った. $\phi 0.1 \mathrm{~mm}$ のコンスタンタン線の一端を偏平にし, 絶縁を施したもの を，分割した試料にはさんで軽く研削を行う。このとき， コンスタンタン線は試料と共に流動を生じ, 絶縁を破壊し て試料と接触し，この点を高温部とする熱電対を形成す る.この出力は増幅器を介して記録計に接続される．温度 較正の際, この接点の近くに, 温度計に接続した標準の $\mathrm{AC}$ 熱電対を和き，光熱源によって加熱し，表面温度と熱 起電力の較正曲線を求めた ${ }^{(13) \sim(15)}$.

残留応力の測定は次のように行った。 まず各種の条件で 研削した誠料について，機械的方法によって残留応力を測 定した. $60 \mathrm{~mm} \times 10 \mathrm{~mm} \times 3 \mathrm{~mm}$ に仕上げた試料を所定の 条件で研削した後，その試料の片面にひずみゲージを貼付

Table 1 Grinding condition.

\begin{tabular}{l|l}
\hline \hline Grinding Wheel & WA $60 \mathrm{H} 8 \mathrm{~V}$ \\
Wheel Speed & $30 \sim 33 \mathrm{~m} / \mathrm{s}$ \\
& $(1800 \sim 2000 \mathrm{~m} / \mathrm{min})$ \\
Work Speed & $0.05,0.1,0.15,0.2 \mathrm{~m} / \mathrm{s}$ \\
& $(3,6,9,12 \mathrm{~m} / \mathrm{min})$ \\
Depth of cut & $10,20,30,40 \mu \mathrm{m} /$ pass \\
Fluid & Dry \\
\hline
\end{tabular}

し，片面の除去を行ら層除去法 ${ }^{(16)(17)}$ によって行った。測 定に用いた式は次のようである，厚さ $h$ の試料を深さ $a$ ま で除去したとき，測定ひずみを $\varepsilon ， こ の$ 深さの応力を $\sigma_{(\mathrm{a})}$ とすると，

$$
\begin{aligned}
\sigma_{(\mathrm{a})}= & -E / 2\left(1-\nu^{2}\right) \\
& \cdot\left[(h-a) \frac{\mathrm{d} \varepsilon}{\mathrm{d} a}-4 \varepsilon+6(h-a) \int_{0}^{a} \frac{\varepsilon}{(h-x)^{2}} \mathrm{~d} x\right] \\
E & : \text { ヤング率, レ: ポアソン比, }
\end{aligned}
$$

また，研削過程である砥石一試料接触域における試料の各 部の残留応力の測定を行うため, $60 \mathrm{~mm} \times 10 \mathrm{~mm} \times 15 \mathrm{~mm}$ の試料を研削の途中でとり出し，これについてX線法によ り残留応力の測定を行った。これには Fig.1に示すよう に, バネの弾性を利用した試料の離脱装置を自製し，研削 中の試料をとり出すこととした。このとき，変位計，デジ タル記録計，シンクロスコープ等を用いて試料の離脱時間 を求めた。ここでは試料が $20 \mu \mathrm{m}$ 離脱するには約 $7.7 \mathrm{~ms}$, $40 \mu \mathrm{m}$ では約 $10 \mathrm{~ms}$ 要した。各試料でそそれぞれ砥石一試 料接触域(接触長さ : $l=\sqrt{ } \overline{D \Delta}, D$ : 砥石直径, $\Delta:$ 切込深 さ)について未研削端(研削の削上り点)を基準点とし，0.3 $\mathrm{mm}$ ずつ離れた部分にX 線を照射し， $0^{\circ}-45^{\circ}$ 法によって 残留応力を求めた。測定には外層を逐次除去し，内部まで の残留応力を求めた (実際にはこの值は除去前の残留応力 とは異るが，その差は微小であるので，測定値を補正しな いで示す)，測定条件を Table 2 に示す．X線照射の際， 第一スリットを $1 / 6^{\circ}$ とすると $\phi_{0}=0^{\circ}$ で試料面の照射幅は 約 $0.5 \mathrm{~mm}, \phi_{0}=45^{\circ}$ で約 $0.75 \mathrm{~mm}$ である。 したがって， 試料を $0.3 \mathrm{~mm}$ ずつ移動させたとき, 求められた結果には オーバーラップしたものが含まれることになる.

このよらに残留応力を測定した試料について，同時に接

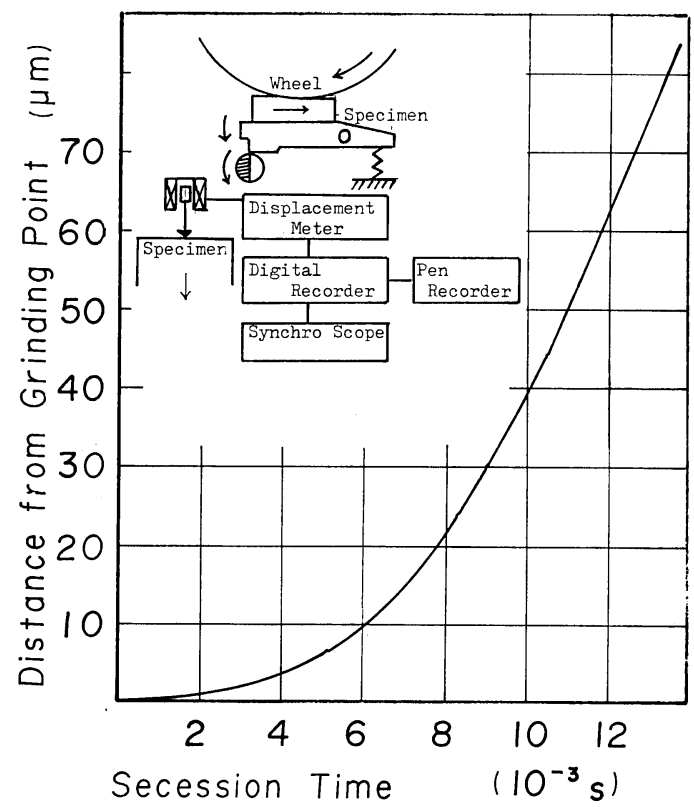

Fig.1 Scheme of gi-inding stop equipment and secession distance from grinding point. 
Table 2 X-Ray condition.

\begin{tabular}{l|l}
\hline Target \& Filter & $\mathrm{Cr} K \alpha, \mathrm{V}$, \\
Voltage \& Current & $30 \mathrm{kV}, 10 \mathrm{~mA}$, \\
Scanning Speed & $1.16 \times 10^{-3} \mathrm{rad} / \mathrm{s}$ \\
& $\left(4^{\circ} / \mathrm{min}\right)$ \\
Count Full Scale & 125 or $250 \mathrm{c} / \mathrm{s}$ \\
Chart Speed & $6.67 \times 10^{-4} \mathrm{~m} / \mathrm{s}$ \\
& $(40 \mathrm{~mm} / \mathrm{min})$ \\
Time Constant & 1 or $2 \mathrm{~s}$ \\
Divergence Slit & $1 / 6$ degree \\
Receiving Slit & $0.3 \mathrm{~mm}$ \\
\hline
\end{tabular}

触面下の各部におけるひずみを測定した。研削を行う以際 し，試料の側面をラップ化上げし，05，06番のエメリ一紙

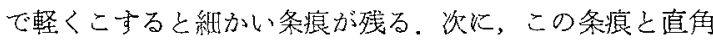

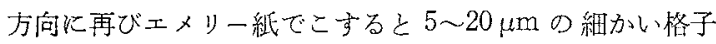
が得られる。この格子面にマークとしてマイクロビッカー スの㾗をつけ，研削前後でその痕近くの格子面の顕微 鏡写真をとる。䄪 1000 倍に引伸ばされた写真に叔いて， 研削面下 20 50 $\mu \mathrm{m}$ の深さの範囲で任意の3 方向につい て，それぞれ適当な2 点在決め，研削の前後でその 2 点間 の長さの変化を求め，こ机より水平方向(研削面方向)之垂 直方向のひず名求めた。

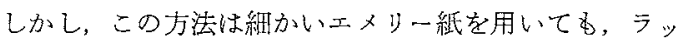
プした側面に残る条痕は顕微鏡写真で約 1000 倍に引伸ば されるためかなり太く，それらの交点も大きくなることか ら，測定精度を高めるために測定回数を多くする必要が
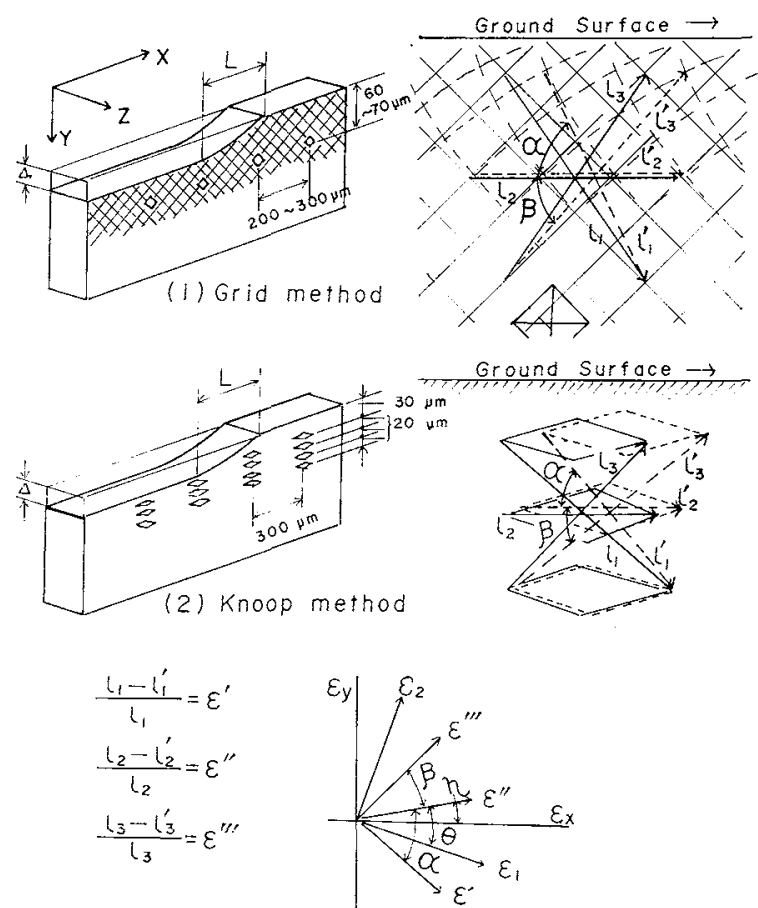

Fig.2 Scheme of workpiece for measurement of distortion below wheel-work contact zone.

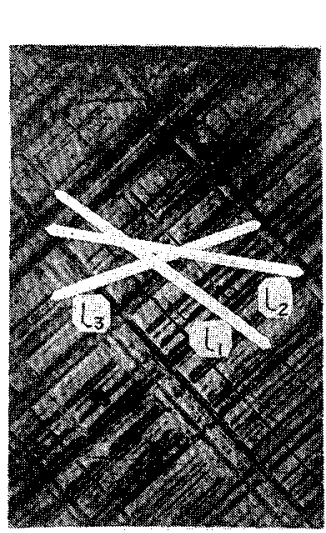

(A) Before Grinding
Grinding Direction

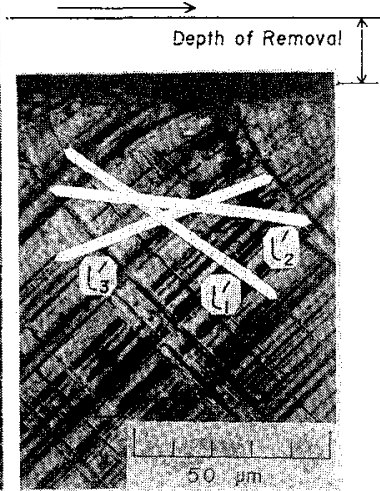

(B) After Grinding

Fig.3 An example of the grid at the side of specimen.

ある、そこですら一つの方法として，同様にラップ仕上げ を行った側面に格子の代りにメープ痕をつける方法をも儌 用した。研削予定面下 $30 \mu \mathrm{m}$ 程度の深さから約 $20 \mu \mathrm{m}$ の 間留で 4 点のヌープ痕をつけ，研削方向には約 $300 \mu \mathrm{m}$ の 間隔で，15〜20 個所にヌープ痕を施した。この場合も，䂰 削前後に顕微鏡写真をとり，生痕の先端間の長さを測定 し，こ机らの長さの変化より，水平方向(研削方向)，重直 厅向のひずみを求めた。 以上，二つのひずみ法をそれぞれ 格子法，ヌープ法と名付けて，Fig.2 にその概䀩を示す。 同図に执いて，(a)格子法，(b) ヌープ法，いずれの場合も 実線は研削前の状態であり，点線は研削後の移動した状態 であり，研削前に測定した長さ $l_{1}, l_{2}, l_{3}$ 方研削後, $l_{1}{ }^{1}, l_{2}{ }^{\prime}$ ，

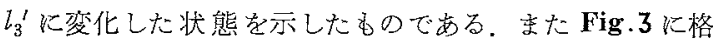

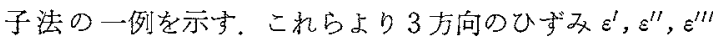

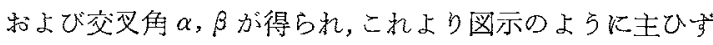
み $\varepsilon_{1}, \varepsilon_{2}$ を計算し，さらに，水平方向ひずみ，垂直方向ひ ずみ $\varepsilon_{\mathrm{X}}, \varepsilon_{\mathrm{y}}$ を求めた，世九断移動量の測定は，格子法に和 ける条痕の移動量を各深さについて測定したもので，5〜7 本の条痕の平均値である。广写真の長さの浿定には 5/100 mm のスケールの測定器を用いたが，写真の伸縮や 視差を考虛すると，測定精度は $2 \sim 3 \times 10^{-3}$ のオーダーで ある。

\section{III. 実 験結 果}

\section{1. 各種研当条件における残留応力分布について}

（1）残留応力分布と試料速度および切込深さの関係

Fig.4 飞機機的与法による残留応力の分有を示すが，そ の分布はすべて最外表部でわずか火低下した部分があらる れるが，直占火急増し，引張応力は最大値となる，その後 再び急激に減少し，ある深さから沐るやかな低下に移るよ

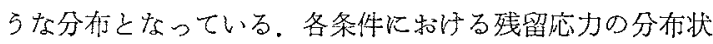
態を詳細にしらべると，試料速度や切込深さによってそれ ぞれ異る様相がみられる。Fig.4亿みられるよらに試料速 度が大となると，切込深さ $10 \mu \mathrm{m} の$ 場合を除いて，20， 


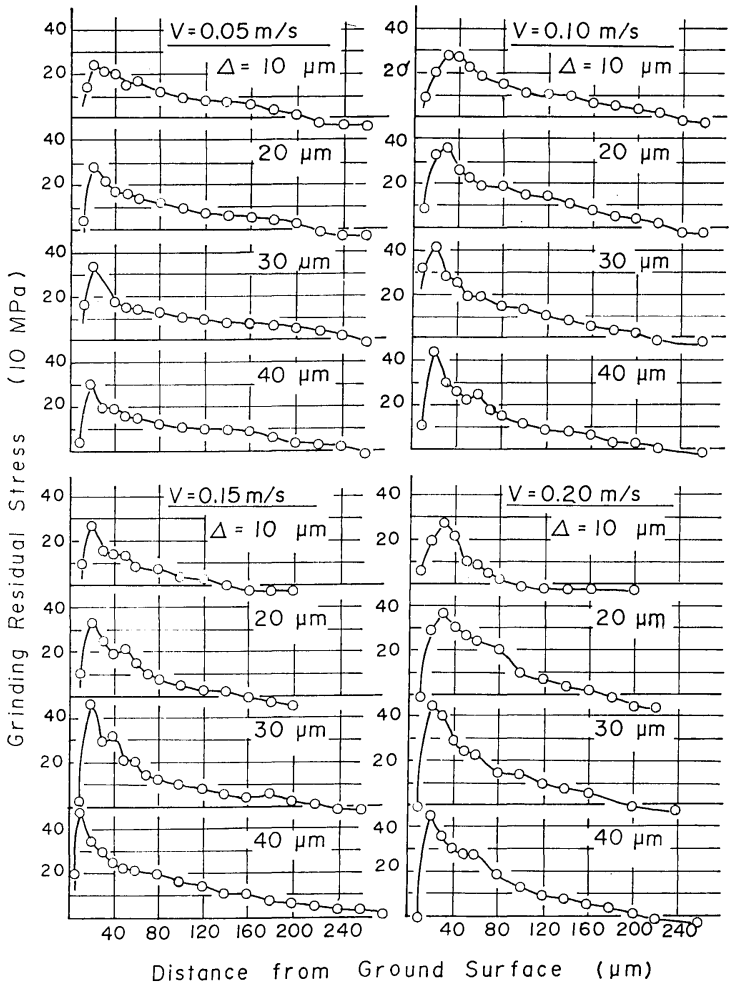

Fig. 4 The distribution of grinding residual stress in various grinding conditions.

30, $40 \mu \mathrm{m}$ のものでは速度が大きくなると最大残留応力は 大となっている。このとき外表より内部にかけての引張応 力部分の表面よりの深さについては, 試料速度が大の場 合，その深さは小であり，また，速度が小の場合に深さは 大となっている.

次に切込深さの影響は，Fig.4でみられるよらに，試料 速度 $0.05 \mathrm{~m} / \mathrm{s}$ の場合は不明膫であるが，それ以上の速度 では，切込深さが大きくなるにつれて最大残留応力の值は 大となる。この傾向は速度の增加の場合と同じである。し かし，このとき最大応力のあらわれる位置は，切込深さの 增加にともなってやや外表に移っていくままた，外表より 内部までの引張応力部分の深さは，切込深さが大となる場 合に大きくなる。この傾向は速度増加の場合とは逆であ る.

\section{(2) 最大残留応力について}

最大残留応力について, 試料速度打よび切込深さとの関 係を示したのが Fig.5 である。同図によれば，最大応力は 切込深さが大きくなると, 試料速度 $0.05 \mathrm{~m} / \mathrm{s}$ の場合は別 として，それ以上の各速度の場合には同じょうな增加を示 している。しかし，試料速度を增加したときの最大応力の 変化は, 各切込深さによって異る。これより，切込深さが 残留応力発生に大きな影響を与えることが推定できる ${ }^{(18)}$.

研削抵抗を求めた結果を Fig.6亿示す，研削抵抗に拉 よぼす試料速度，切込深さの影響としては，水平抵抗，垂 直抵抗のいずれも試料速度，切込深さが大となると，最大

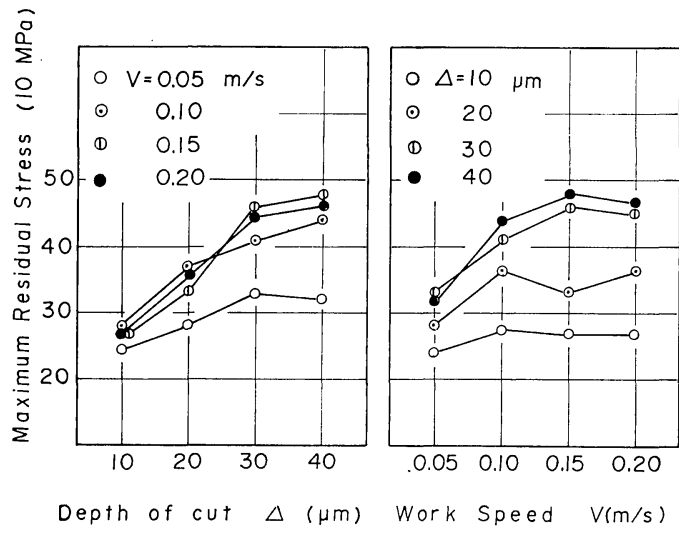

Fig.5 Relations between maximum residual stress and grinding conditions.

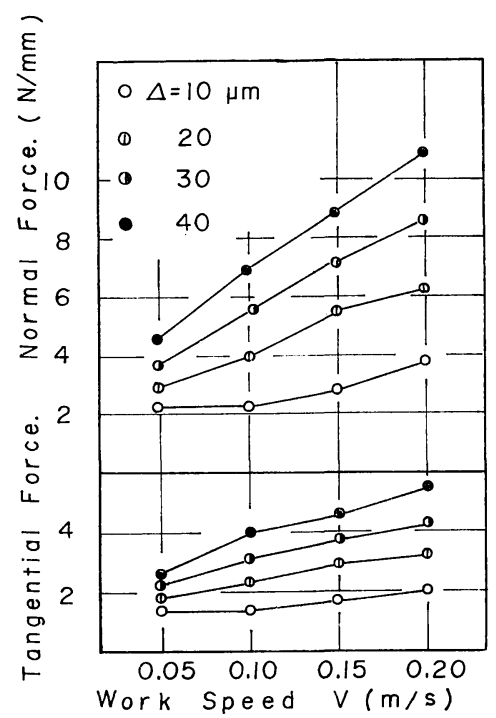

Fig.6 Relations between grinding forces and grinding conditions.

残留応力の場合と同じょうに増加している。これについて は, 普通研削抵抗が大きい程, 研削熱の発生も大となるこ とはよく知られており，このため熱応力を生起し，引張残 留応力が発生すると考えると, 外表部の最大残留応力に対 し，これら水平抵抗，垂直抵抗が関係していることがわか る.

研削面温度の測定結果を Fig.7 亿示す。温度は試料速 度, 切込深さのいずれによっても変化する ${ }^{(19)}$ 。このうち, Fig. 5 の最大残留応力の場合と同じく，切込深さによる影 響の方が試料速度の場合より明嘹である。

つぎに，最大残留応力と研削温度との関係を Fig.8 に 示す，温度が大きくなると最大応力も大きくなり，試料速 度の小さい $0.05 \mathrm{~m} / \mathrm{s}$ の場合はややこの関係からはずれる が，温度と最大残留応力の関係は一応対応している。試料 速度, 切込深さがある条件範用では，いずれの条件の場合 も，最大残留応力は，その研削面温度に関係することが知 られる。 


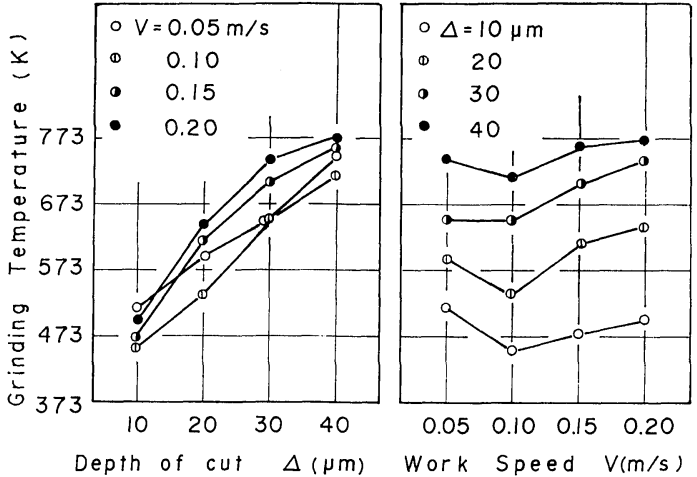

Fig.7 Relations between grinding temperature and grinding conditions.

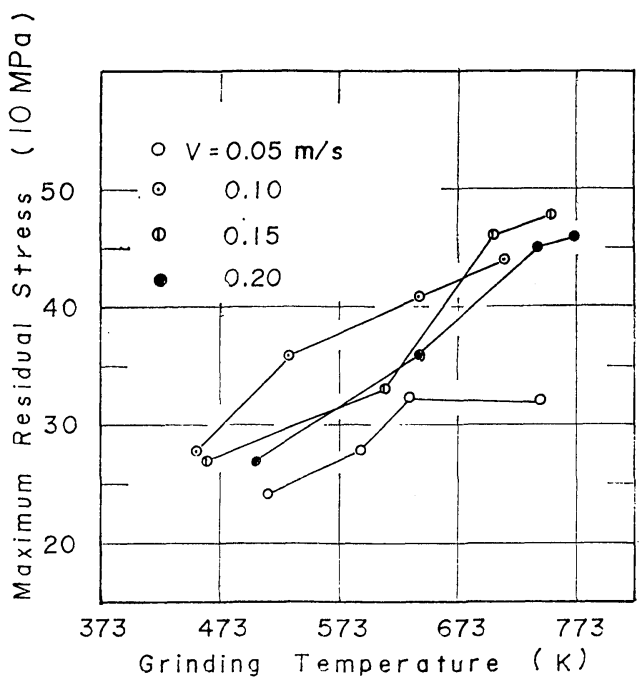

Fig. 8 Relations between maximum residual stress and grinding temperature.

\section{2. 残留応力の発生に関する検討実験}

從来, 研削に上る残留応力の発生原因の殆どは熱的作用 によるものとされていた。 ここでも，その最大残留応力に ついては，研削面温度とょく対応することから，少なくと も最外表部にあらわれる最大応力值については，熱的原因 によるものと考光られる。しかし，外表より内部にかけて の残留応力の分布全体について考光ると，表面より内部に ゆくと，熱の影響は急速に小となるはずであるが，かなり 内部まで引張残留応力であること，また，これらの残留応 力が試料速度や切込深さの大小によって，特徴ある分布が 得られることなどから，ここで残留応力の発生について, 研削時, 表面下に执いて, 外力の効果で生じる塑性変形の 影響る検討する必要があると思われる。この目的のため, 実験方法のところで述べたように，研削を中途で停止し， 砥石一試料接触域を残して取出した試料について, 未研削 端より，それぞれ $0.3,0.6,0.9,1.2,1.5,1.8 \mathrm{~mm}$ はな れたところの，招の扮のの部分について表面下の塑性ひず みの測定を行った。

\section{(1) ひずみの測定結果}

Fig.9 亿研削面下における，研削方向と垂直方向のひず 及 $\varepsilon_{\mathrm{x}}, \varepsilon_{\mathrm{y}}$ の測定結果を示す。ここで求められたひずみは表 面下約 $20 \mu \mathrm{m}$ から $50 \mu \mathrm{m}$ の深さの部分に打ける平均ひず みである，表面直下の $\varepsilon_{\mathrm{x}}, \varepsilon_{\mathrm{y}}$ の測定は困難であった。また Fig.10 亿表面から内部にかけてのせん断移動量を示す. ここで表面下の各部での実際の垂直ひずみの状態は，実測 したせん断移動量の測定結果から推察すると，せ九断移動 と垂直ひずみの発生が同じ原因であるとすれば，両者は無 関係ではないと考兄られ，この垂直ひずみもせん断移動と 同じょうに，外表より内部にかけて深く存在しているもの と考光る。

残留応力の発生に関係して $\varepsilon_{\mathrm{x}}, \varepsilon_{\mathrm{y}}$ の状態をみると，まず $\varepsilon_{\mathrm{x}}$ については，材料が連続状態であれば，外表近くの表 面下では，水平方向ひずみ $\varepsilon_{\mathrm{x}}$ は塑性ひずみに弾性的応力 によるひずみが加わったもので，その状態は零に近いはず である，垂直ひずみ $\varepsilon_{\mathrm{y}}$ にいては外表部は自由であり， ここで外表方向の応力は零である。 そこで垂直方向のひず み后については塑性ひずみであって，これは伸縮の值を 自由にとり得る。また， $\varepsilon_{\mathrm{x}}$ に直角な板幅方向のひずみ $\varepsilon_{z}$ は，板幅が十分広く， $\varepsilon_{\mathrm{x}}$ にくらべて小さいので，ここでは 近似的に $\varepsilon_{\mathrm{z}}$ を零と报く。

そこで，体積不変の考党から，例光ば垂直方向の塑性ひ ずみが収縮であ机ば，この部分の表面に平行な方向の塑性 ひずみは伸長となり，そのため，この方向には圧縮残留応 力が発生することがわかる。 また $\varepsilon_{\mathrm{y}}$ が伸長ひずみのとき は, 同様にして表面に平行な力向に引張残留応力が生じ る。このように，表面下のひずみの状態も残留応力の発生 に関係する。

Fig.9 より，実際に表面下にあらわれるひずみの発生状 態をみると，社はあまり大きくない，残留応力に関係す るものとして垂直ひずみ $\varepsilon_{\mathrm{y}}$ に注目すると，いずれの場合 も同じよらな傾向であらわれている. 平均垂直ひずみ $8 y$ は 未研削端より $0.3,0.6,0.9 \mathrm{~mm}$ 之位置が移ると, 圧縮ひ ずみが大きくあらわれ，これが $1.2 \mathrm{~mm}$ 付近になると減少 しこれ以上では引張ひずみになってゆく.

普通，外力がなく，単に発熱のみによる熱応力が原因の ときは，発熱沙よる体積膨張抑制のため，表面にとった $x$ 方向には圧縮ひずみを生じ，垂直方向には伸長の塑性ひ ずみとなる。この場合は表面下 $20 \sim 50 \mu \mathrm{m}$ の部分の垂直 塑性ひずみであるが，研削のかなり進んだ状態では垂直方 向は引張ひずみであるが，研削の初期においては引張ひず みではなく，大きな生縮ひずみがみられる。このことは， 熱的な影響があるとしても，外部からの力学的影響が加わ ったことによるものと考觉られる。そして，結果としての 残留応力は，もちろん， $x$ 方向の塑性ひずみが第一原因で あり，このような垂直ひずみの影響は 2 次的な原因と考兄 られ，これは後述の上らに，内部の残留応力分布に影響す る. 


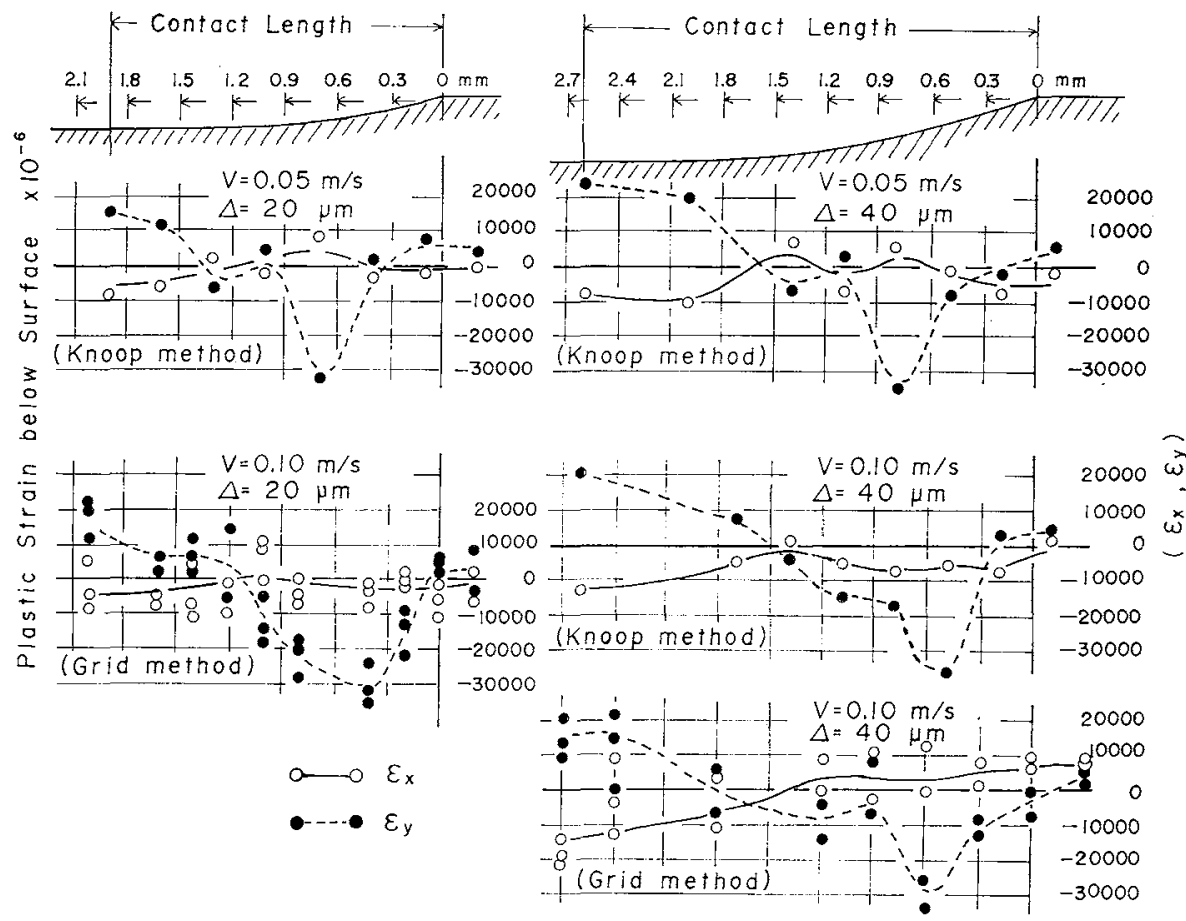

Fig.9 Plastic distortions below wheel-work contact zone.

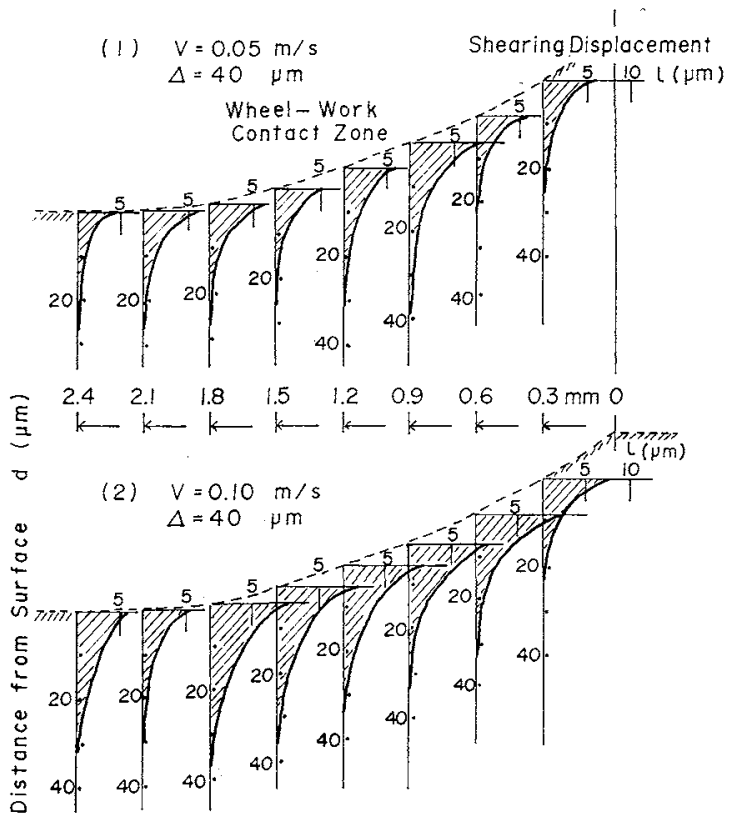

Fig.10 Shearing displacement below wheel-work contact zone.

和の和のの場合について述べると，試料速度の影響とし ては，切込深さ $20 \mu \mathrm{m}$ の場合，試料速度が大さくなると， 末研削端より圧縮側にあらすれた垂直ひずみ $\varepsilon_{y}$ の最大部 が未研削端側に移行し，全体としての圧縮ひずみ部分も大 となっている．切込深さ $40 \mu \mathrm{m}$ の場合も同様である， 1.5 $\mathrm{mm}$ 以上離れた点では $\varepsilon_{\mathrm{y}}$ は伸びひずみとなり，これ以降 の状態においてはあまり差がない.
このことと Fig.4 に示した残留応力の湘定 結果と対比 してみると，最大残留応力は別として，試料速度が大きく なると，外表より内部へかけての分布に和いて，大の引張 応力部分の樑さがより小となっている。このことは，莗直 ひずみ しているが，ここで，残留応力ではその内部に和いて，試 料速度の大きいものは，小さいものKくらへ，引張応力部 分が小となり，すなわち，正穛応力側火移行している．前 述のように，垂直ひずみ $\varepsilon_{\mathrm{y}}$ の圧縮ひな゙みが大きくあらわ れることは，2 次的ではあるが，圧縮残留応力を生じる原 因になるとすると，この力学的影響によるひずみがさらに 表面下 $50 \mu \mathrm{m}$ 以下でも存在し，研削が進んだ状態になっ てもかなり残存して，残留応力に影響を与克ていると考光 ると，雨者の関係は符合する。

次に切込深さの影響の場合を述べる。試料速度 0.05 $\mathrm{m} / \mathrm{s}, 0.1 \mathrm{~m} / \mathrm{s}$ いずれの場合も，末研削端より $0.6 \mathrm{~mm}$ 付 近にみられる $\varepsilon_{\mathbf{y}}$ の圧縮ひずみの大きさに大差ないが， $\varepsilon_{\mathbf{y}}$ はこの付近より内部の引張側にらつる部分が，分布に多少 の属曲はあるが，切込深さが大きくなると，1.2 mm 付近 から $1.5 \mathrm{~mm}$ 付近に移行し，立た最終状態の引張ひずみ は，切込深さの大きい場合は明らかに大となっている。

残留応力の分布との対比を考学ると，末ず垂直ひずみ 气y Kついては，研削初期にあらかれて，圧縮残留応力の原 因になる压縮ひずみは表面下，このよらにあるいはこれ以 下でもかなり残存するとしても，切达深さが大きいとき は，この压縮ひずみはより多く除去される。またこのと き，研削行程の終りにあらわれる引張ひずみも大きい。こ 
れは残留応力分布に执いて，まず内部での，引張残留応力 部分が，切込深さが大きいほど大きく，また，表面近くま での，全体としての残留応力部分も大となっていることに 対応する。このように, 残留応力の発生の主な原因は, 熱 応力による外表部での引張残留応力発生によることはもち ろんのことであるが，上記のようと研削初期の未研削端近 くにあらわれる，このよらな塑性变形の影響もかなり関係 することが考觉られる.

\section{（2）砥石 - 試料接触域の残留応力について}

ここでの残留応力の測定はX線法によって行ったもので ある。ここでの結果は, 最外表は明膫な引張応力であり， 外表部にやや低い応力があらわれる機械的測定法の場合と は異る。これはX線の侵透深さが $10 \mu \mathrm{m}$ 程度 $(\mathrm{CrK} \alpha)$ であ り，応力值はこの部分を含む平均值であること，また機珹 的測定法の場合, 除去深さ ひずみ関係曲線の勾配から計 算を行ったもので，直接の測定值でないことによる.

Fig.11は未研削端より $0.3,0.6,0.9,1.2,1.5,1.8$ $\mathrm{mm}$ はなれた各点について, その部分の表面および表面下 の残留応力をしらべたものである，まず，試料速度の影響 についてのべる．各部の残留応力分布としては，切込深さ $20 \mu \mathrm{m}$ の場合, 各試料速度に沶いて, 未研削端より 0.3 $\mathrm{mm}$ の付近ですでに残留応力を生じ，その表面下 10２0 $\mu \mathrm{m}$ の深さで変動した分布となり，未研削端より $0.6,0.9$ $\mathrm{mm}$ でこれが変化し， $1.2 \mathrm{~mm}$ で变化の終ったような分布 となりまた $1.5 〜 1.8 \mathrm{~mm}$ になると若干変化したような 分布になっている. 切込深さ $40 \mu \mathrm{m}$ の場合でも同じよう な分布である。両者とも，試料速度の大きいるのは 0.3 ， $0.6,0.9 \mathrm{~mm}$ の部分に猢る残留応力は全体として小さ い.このとき，前述の $\varepsilon_{\mathrm{y}}$ の圧縮ひずみが表面下に大きく 存在して影響を与兄ている場合に相当する。また， $0.3 ，$ $0.6,0.9 \mathrm{~mm}$ の点に批る表面よりの応力分布において,
引張残留応力の分布が下方にわん曲し，応力が低下したよ らな状態がみられる。これは明らか飞 $\varepsilon_{\mathrm{y}}$ の収縮ひずみの 影響によるものであるう。

次に，切込深さの影響についてみると，いずれの試料速 度の場合に执いても，未研削端上り $0.3,0.6,0.9 \mathrm{~mm} の$ 各点の残留応力分布の状態は, 切込深さの大きいものは, まず，最外表部に大きな引張残留応力を生じている，これ はもちろん，まず研削熱の影響によるものと考光られる。 各点飞打礼応力分布の状態では, 未研削端より $0.3,0.6$, $0.9 \mathrm{~mm}$ 離れた位置で, 引張残留応力の分布が屈曲して低 下している部分が，しだいに深い位置にあらわれている． 未研削端より $1.2,1.5,1.8 \mathrm{~mm}$ 離れた部分にかけての応 力分布では, 切込深さの大きい方がここでは明らかに大き な引張残留応力を生じている。これらは，前述したよらに 切込深さの大きい方が研削初期に生じた収縮ひずみが大き く除かれること，また，研削の進んだ状態で，垂直ひずみ がより大きく引張に移行することにも対応する。

\section{IV. 結 言}

$0.45 \% \mathrm{C}$ 炭素鋼材の試料について, 各種の条件で研削を 行ったものについて残留応力を調べ, 残留応力発生に拈よ ぼす研削条件の影響や残留応力発生の原因について検討し た.

（1）研削による残留応力は，いずれの条件の場合子外表 部に大きな引張残留応力を生じる。 そして, 残留応力の分 布に颃いて，試料速度や切达深さを変えた場合，それぞれ 特徵のある分布がみられる。

(2) 研削過程中の砥石 - 試料接触域の各点の表面下のひ ずみと残留応力を調べた結果, 研削初期の未研削端近くで 表面下 $20 \sim 50 \mu \mathrm{m}$ 飞扮いても，表面に垂直な方向に大き な圧縮ひずみが存在することが知られ，研削の進んだ接触

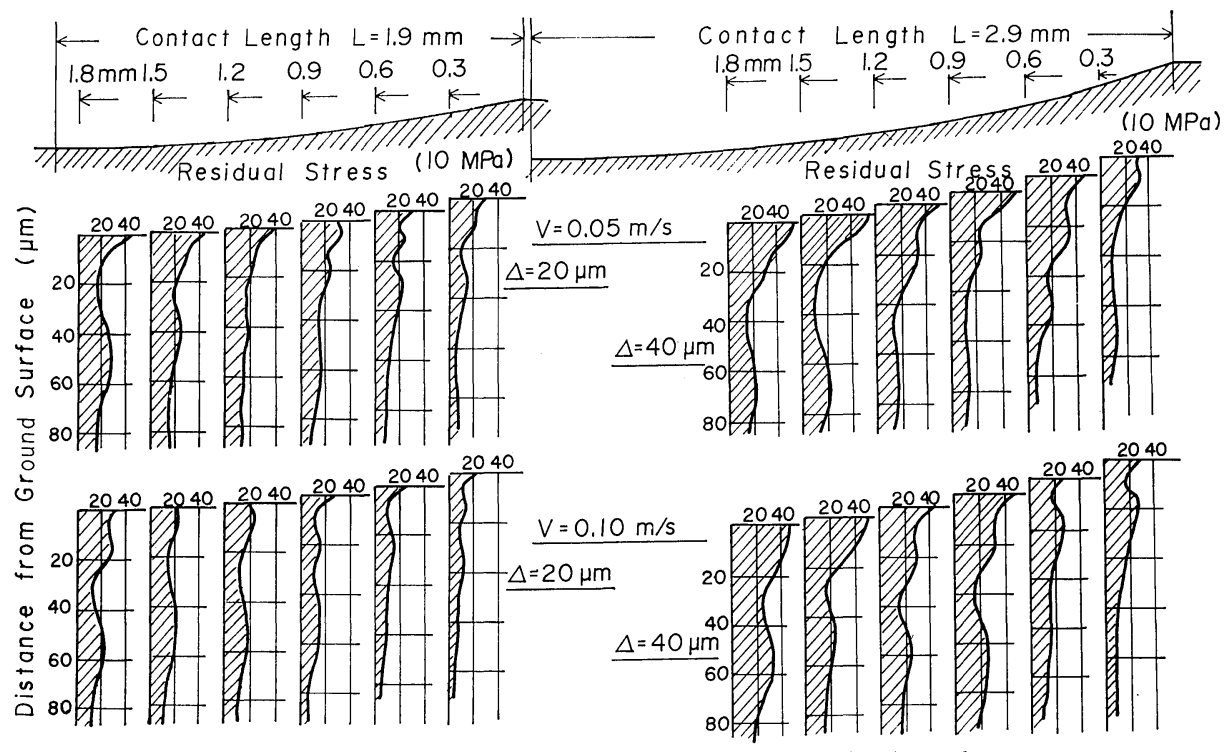

Fig.11 The distribution of X-ray residual stress below wheel-work contact zone. 
域の各部でこれが変化し，最終的には引張ひずみとなり， 残留応力の発生に関係することが知られた。

残留応力の発生原因は, 主として研削熱の影響による熱 的原因によるものと思われるが，詳細にみると，このよう な試料と砥石との接触面下で生じた力学的効果による塑性 変形の影響も考慮すべきものと考える。

\section{文献}

(1) E.K.Henriksen : Trans. ASME, 73 (1951), 69

(2) H.R.Letner and H.J.Synder : Trans. ASME, 75 (1953), 873.

(3) 西本 廉: 精密機械, 30 (1964), 121.

(4) H.Bühler and H.D.Klein:Werkstatt und Betrieb, 102 (1969) , 845

(5) J.H.Kahles and M.Field : Proc. ICPE, (1974-8), 95.

(6) W.E.Littmann : Proc.ICPE, (1967), 1308.
（7）貴志浩三，江田 弘：日本金属学会誌，35(1971)， 896.

（8）鍵和田忠男，斉藤勝政：日本 機械学会論文集，43， $372(1977), 3125$.

（9）江田 弘, 貴志浩三, 大久保昌典 : 精密機械, 45 (1979), 1347.

（10）江田 弘, 貴志浩三, 大久保昌典, 上野秀雄 : 精密 機械, 47 (1981)，314.

(11) 大越諄：理研彙報，第十一輯四号，(1931)，606.

(12) C.T.Yang : Trans. ASME, 90 (1968), 127.

(13) W.E.Littmann and J.Wulff : Trans. ASM, 47 (1955), 692.

(14) J.Peklenik : Industrie-Anzeiger, 1-3 (1958), 10.

(15) 津和秀夫, 山田弘文, 河村未久 : 精密機械, 41 (1975) , 358.

(16) F.Staeblein : Kruppsche Monatshefte, 12 (1931), 93.

(17) 米谷 茂 : 残留応力の発生と対策, 養賢堂, (1975).

(18) J.Frisch and E.G.Thomsen: Trans. ASME, 73 (1951), 337.

（19）高沢孝哉：精密機械，30(1964)，914. 